\title{
テープターゲットを用いたレーザープラズマEUV光源による 光電子分光装置の開発
}

\author{
西村 靖彦 ${ }^{1}$ ，高橋 全 $^{1}$, 坂田 篤 ${ }^{1}$, 東 博純 ${ }^{2}$, 山口 直洋 ${ }^{3}$, 原 民夫 ${ }^{3}$ \\ 1(株) トヨタマックス ( $4771-0826$ 愛知県豊田市トヨタ町2番地) \\ 2 (株) 豊田中央研究所 (广480-1192 愛知県愛知郡長久手町) \\ 豊田工業大学 ( $=468-8511$ 愛知県名古屋市天白区久方2-12-1)
}

\section{Development of Photoelectron Spectromicroscope with Laser-Produced Plasma EUV Light Source Using Tape-Target}

\author{
Yasuhiko NISHIMURA, ${ }^{1}$ Zen TAKAHASHI, ${ }^{1}$ Atsushi SAKATA, ${ }^{1}$ Hirozumi AZUMA, ${ }^{2}$ \\ Naohiro YAMAGUCHI, ${ }^{3}$ and Tamio HARA ${ }^{3}$ \\ ${ }^{1}$ TOYOTA MACS INC., 2, Toyota-cho, Toyota, Aichi 471-0826 \\ ${ }^{2}$ TOYOTA Central R\&D Labs., Inc., Nagakute, Aichi 480-1192 \\ ${ }^{3}$ TOYOTA TECHNOLOGICAL INSTITUTE, 2-12-1, Hisakata, Tempaku, Nagoya, Aichi 468-8511
}

(Received June 11, 2004)

\begin{abstract}
A photoelectron spectromicroscope with a monochromatized laser-produced plasma EUV light source has been developed, and its performance was investigated. The monochromatized laser-produced plasma EUV light source can operate at $50 \mathrm{~Hz}$ repetition rate. First, various experiments were carried out to investigate the characteristics of this EUV light source. When an aluminum tape-target was used to produce $13 \mathrm{~nm}$ radiation, it was observed that there exists an optimal irradiation intensity of the laser beam for excitation. It turns out that the power density ranging from $400 \mathrm{GW} / \mathrm{cm}^{2}$ to $500 \mathrm{GW} / \mathrm{cm}^{2}$ on a target is required. Besides, a spatial distribution of the main spectral line radiation was measured in the cross sectional view to the plasma. It was found that there was a region where the $13 \mathrm{~nm}$ radiation is dominant, which exists at the position about $1 \mathrm{~mm}$ away from the target surface. Moreover, the absolute radiation intensity of the $13 \mathrm{~nm}$ radiation in the EUV light source was measured and estimated to be $4[\mathrm{~mJ} / 2 \pi \mathrm{sr} / \pm 2 \% \mathrm{BW} / \mathrm{pulse}]$.

Then, by using this developed photoelectron spectromicroscope, photoelectron spectrum observation has been performed. When a GaAs wafer was used as a sample, photoelectron spectra of Ga-3d and As-3d in GaAs were observed. At present, spatial resolution of less than about $5 \mu \mathrm{m}$ could be obtained. This result shows that the developed photoelectron spectromicroscope can be applied to valence-band electron analysis successfully.
\end{abstract}

Key Words: Photoelectron micro-spectroscopy, Laser-produced plasma, Monochromatized EUV light, Aluminum tape-target.

1.はじめに

従来，半導体素子表面の久陥・検査においては，SEM (走査型電子顕微鏡) や従来型X線光電子分析装置 $(X P S$ ま たはESCA装置)などが用いられている．X線管を用いた光 電子分光技術では, 数 $\mu \mathrm{m} の$ 分解能しか得られていないの が現状である。また，従来手法ではエネルギーが高くな ることや輝度が低いため試料表面数nmにおける元素及び 化学結合状態を得ることが難しい. そこで, 第3世代の放 射光を用いた軟X線光電子顕微鏡分析が活発に行われてい るが1,2), マシンタイムや装置コストの点から, 製造現場 や研究室レベルで使用できる光電子顕微鏡装置開発が期 待されている。その中，レーザープラズマ光源とTOF法を 用いたXPS装置の研究開発が報告され ${ }^{3)}$, 文部科学省科学
技術振興調整費 (1999 2003年度)による実用化研究も進 められてきた。 その中で, 我々は「レーザープラズマ生成 技術の研究」を実施し，レーザープラズマ光源の分布にお いて局在的な領域からEUV光を引き出すことによってあ る程度鏡帯域化を行う方法を提案してきた ${ }^{4)}$. この方法に よればEUV光の単色化のために回折格子のような分光素 子を使わないで, レーザープラズマ強度を低下させるこ となしにEUV光を利用することが可能になる。

また，2002年度より2003年度に実施した「地域新生コン ソーシアム」事業「線集光型X線源を用いた高分解能光電子 顕微鏡装置の開発」では, レーザープラズマEUV光源と従 来型分析装置との融合を目指した光電子分析装置の開発 を進めてきた5).

これが実現すると，新規に新しい分析装置を導入する 
ことなしに光電子顕微鏡を手にすることができるので, 昨今の経済状況の中, 企業や大学などの研究室にとって 望ましい技術である。

本報告では，これらのプロジェクトにより得られた知 見を基に開発したレーザープラズマEUV光源による光電 子分析装置について報告するものである，具体的には， 単色化されたEUV光を発生させるための候補となるター ゲットとして波長 $13 \mathrm{~nm}$ を発光するアルミニウムテープ ターゲットを開発し, 同ターゲットへの最適照射強度,

EUV光の取出し位置など最適化を行った。 基礎実験結果 を基に，50 Hzの繰返運転が可能なレーザープラズマEUV 光源を開発した。開発した光源と従来型分析装置である エネルギー分散型分析装置と結合した光電子分析装置を 試作し, 試料としてGaAsを用いて光電子スペクトル観察 を行った。 また，試作した分析装置の空間分解能につい ても評価を行った。

\section{2. 実験装置}

2.1 レーザープラズマEUV光源開発用実験装置

光電子分析装置用レーザープラズマ光源に使用する ターゲットの選定，ターゲットへの最適照射強度を求め るために用いた実験装置をFig. 1に示す. 本装置は, 励起 用レーザー (Quanta-Ray: model GCR-290-10)からのレー ザー光 (wavelength: $532 \mathrm{~nm}$, pulse duration: 7ns, energy/pulse: $0.8 \mathrm{~J})$ を真空容器内に配置したターゲットに集光照射して レーザープラズマを生成する装置である。同装置は夕ー ゲット上での照射強度を約 $10^{10} \sim 10^{11} \mathrm{~W} / \mathrm{cm}^{2}$ の範囲で変え ることができるよう集光レンズ $(f=300 \mathrm{~mm})$ に精密ステー ジが取り付けられており，調整が行えるシステムとなっ ている。そして生成されたプラズマからのEUV光は, ターゲット面に平行方向に配置した平面結像型斜入射回 折格子分光器を用いて観察した. 分光器はトロイダルミ ラー，スリット，回折格子(日立製:1200 lines/mm) とEUV 光検出器から構成される. トロイダルミラーへの斜入射 角度は $2^{\circ}$ とし, 回折格子への斜入射角度は $2.8^{\circ}$ である。 ターゲットとトロイダルミラー間の距離はトロイダルミ ラーとスリット間の距離の約6倍であるので，例えばス リット幅 $100 \mu \mathrm{m}$ の時，ターゲット法線方向に対する空間 分解能は約 $600 \mu \mathrm{m}$ となる. また, EUVスペクトル検出に

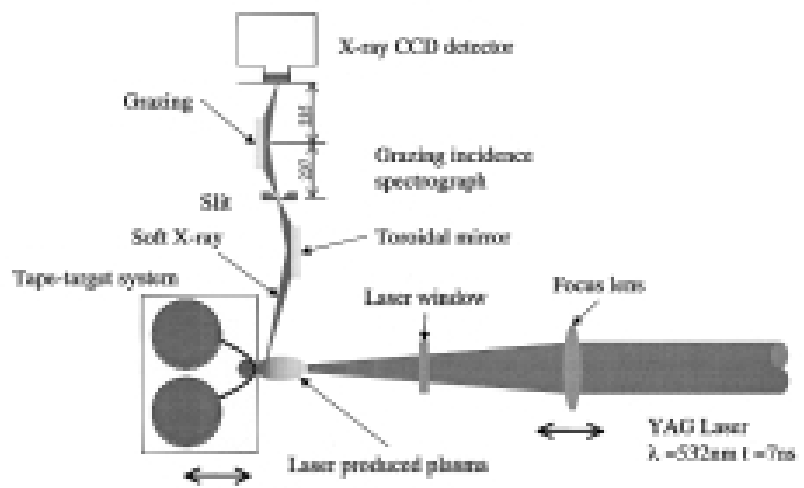

Fig. 1 Experimental set-up of laser-produced plasma source.
は，背面照射型X線CCDカメラ (Princeton Instruments社製: SX-TEA/CCD-1024-TKB/1 セルサイズ : $24 \mu \mathrm{m} \times 24 \mu \mathrm{m})$ を 使用した。

\section{2 光電子分析装置用レーザープラズマ光源開発}

Fig. 2に示すような $50 \mathrm{~Hz}$ に対応した光電子分析装置用 レーザープラズマEUV光源装置を開発した. 同装置の光 源部は，励起用レーザー (Continuum: Powerlite Precision 9050) からのレーザー光 (wavelength: $532 \mathrm{~nm}$, pulse duration: 4〜8 ns, energy/pulse: $0.6 \mathrm{~J})$ をテープ上に形成されたアルミ ニウムテープターゲットを $50 \mathrm{~Hz}$ の繰返し周波数で供給可 能な供給装置と, ターゲットから発生するデブリから レーザー入射空を保護するデブリストッパー，生成され るプラズマからのEUV光以外の進入の取り込み領域を制 限する迷光防止板 $(\phi=20 \mathrm{~mm})$ の開口上に配置したBeフィ ルター $(\mathrm{t}=200 \mathrm{~nm})$, ターゲット面に沿った方向からのデ ブリからシュバルッシルトミラーを保護するための斜入 射ミラー, 及び照射パルス制御装置, フェイルセーフ回 路など様々な装置により構成されている。.さらに光源 チャンバーには, 平面結像斜入射回折格子分光器接続 ポートが設けられており, 発生するEUV光スペクトルの 観察が可能となっている.

\section{3 光電子分析装置}

Fig. 2 に示すエネルギー分散型分析装置 (PHI社製： MODEL 10-360 改良型)を用いて試料物質の光電子スペク トル観察を行った。同分析装置は，主にシュバルッシル トミラー, サンプルホルダー半球型電子エネルギー分析 器, 積分型電子検出部から構成されている. 試料から発 生した光電子は光電子検出口から半径 $279.4 \mathrm{~mm}$ の半球型 エネルギー分析器 (検出可能エネルギー範囲は, 〜 $1 \mathrm{keV}$ ) へ導かれ，下流側に配置された検出用 $\mathrm{MCP}(\mathrm{F} 1208-01: 2$ 段増幅型, 直径 $30 \mathrm{~mm}$ )により検出される。そして 背面には蛍光面(蛍光体 P20) を配置し，MCPからの電子を 可視化し, 真空容器外に配置したCCDカメラ (浜松ホトニ クス製： ORCA II-ER) で観察するシステムとなっている. このCCDカメラにより暗電流が低く抑えられ, 高感度で 長時間の画像蓄積に優れている。一回のエネルギー測定 範囲はMCP及びCCDカメラに依存しており約50 eVであ る. そしてエネルギー分解能 $\Delta \mathrm{E}$ は予備試験結果から $0.6 \mathrm{eV}$

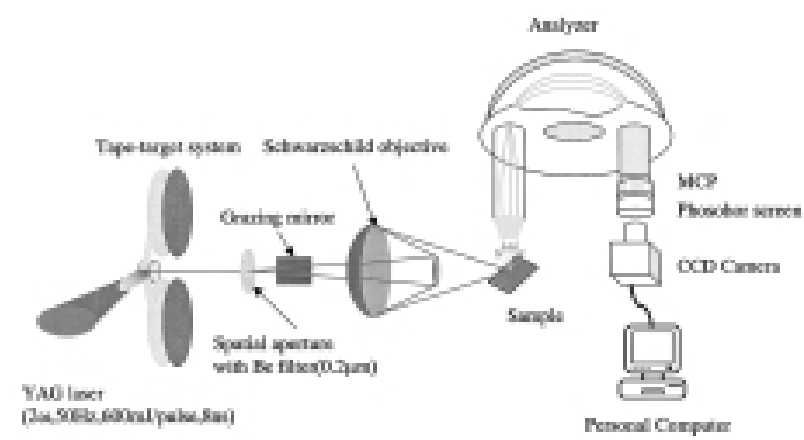

Fig. 2 Experimental set-up for the photoelectron microscope. 
であった。サンプルホルダー（最大取り付け試料サイズ： $10 \mathrm{~mm} \times 40 \mathrm{~mm})$ は, 真空容器外部から4軸移動調整可能な システムが構築されており, 微動させるための高精度ピ エゾステージも組み込まれている.

\section{3. 実験結果と考察}

3.1 ターゲット選定とEUV光発光空間分布

エネルギー $(h v)$ の光子が照射されると被測定試料中の 電子は, 光子からもらったエネルギー $(h v)$ から電子の束 縛エネルギー $\left(E_{\mathrm{B}}\right)$ と仕事関数 $(W)$ だけのエネルギーを失っ て伝導体の真空準位より上の準位に励起され運動エネル ギー $\left(E_{\mathrm{K}}\right)$ をった光電子として現われる。この関係を式 で示すと式(1)となる.

$$
E_{\mathrm{K}}=h v-E_{\mathrm{B}}-W
$$

そこで，単色化されたEUV光を発生させるために，候 補となるターゲットの選択を行った. Table 1に代表的な元 素の各遷移における波長と強度を示したものである6).ま た，参考文献7）や8）に示されるように原子番号の小さいイ オンでは, 比較的高輝度の線スペクトルを有することか ら, 強度が高く, 加工性がよく, 必要とする波長帯に複 数の輝線スペクトルが少ないアルミニウムを選び，波長
$13 \mathrm{~nm}($ 約 $95.4 \mathrm{eV})$ を用いることとした。アルミニウムの場 合, 必要とする波長 $13 \mathrm{~nm}$ に近い強い線スペクトルとして は波長 $16 \mathrm{~nm}$ 付近のEUV光が存在するが，これは3価のア ルミニウムイオン $\left(\mathrm{Al}^{3+}: 1 \mathrm{~s}^{2} 2 \mathrm{~s}^{2} 2 \mathrm{p}^{6} \rightarrow 1 \mathrm{~s}^{2} 2 \mathrm{~s}^{2} 2 \mathrm{p}^{5} 3 \mathrm{~s}\right)$ からの EUV光であり，波長 $13 \mathrm{~nm}$ のEUV光は，4価のアルミニウ ムイオン $\left(\mathrm{Al}^{4+}: 1 \mathrm{~s}^{2} 2 \mathrm{~s}^{2} 2 \mathrm{p}^{5} \rightarrow 1 \mathrm{~s}^{2} 2 \mathrm{~s}^{2} 2 \mathrm{p}^{4} 3 \mathrm{~s}\right)$ からのEUV光であ るため, イオン価が異なる波長 $13 \mathrm{~nm}$ と波長 $16 \mathrm{~nm}$ のスペ クトル強度を比較することにより，生成されるプラズマ の空間分布を予測することができる. また, 開発する光 電子分析装置において, レーザープラズマEUV光源で生 成される波長 $13 \mathrm{~nm}$ のEUV光を集光させる際, 多層膜ミ ラーを用いるため，多層膜ミラーの反射波長域から外れ た波長 $16 \mathrm{~nm}$ のEUV光は殆ど反射しないため, 光源に波長 $16 \mathrm{~nm}$ 若干残っていても，それほど大きな問題とならな い.

次に, 研究開発をしている光電子分析装置では, レー ザープラズマEUV光源を開発するにあたって, 試料に対 して照射するEUV光を微小領域に絞る必要性がある。そ のためには，光源を小さく制限する必要がある。従っ て, 光源プラズマのどの部分から励起用EUV光を引き出 せば最も効率良くシュバルッシルトミラーに導くことが 出来るか知らなければならない。 そこで, 選択した夕ー ゲットから生成されるプラズマの空間分布を詳細に観察

Table 1 Binding energy and kinetic energy photoelectron from GaAs.

\begin{tabular}{|c|c|c|c|c|c|c|c|}
\hline $\begin{array}{l}\text { Wavelength } \\
{[\mathrm{nm}]}\end{array}$ & $\begin{array}{l}\text { Intensity } \\
\text { [A.U.] }\end{array}$ & Z.CHARGE & Element & $\begin{array}{l}\text { Wavelength } \\
{[\mathrm{nm}]}\end{array}$ & $\begin{array}{l}\text { Intensity } \\
\text { [A.U.] }\end{array}$ & Z.CHARGE & Element \\
\hline 12.903 & 50 & 10.04 & $\mathrm{Ne}$ & 13.0344 & 180 & 12.03 & $\mathrm{Mg}$ \\
\hline 12.904 & 200 & 11.05 & $\mathrm{Na}$ & 13.0354 & 180 & 12.03 & $\mathrm{Mg}$ \\
\hline 12.914 & & 17.16 & $\mathrm{Cl}$ & 13.039 & & 13.03 & $\mathrm{Al}$ \\
\hline 12.9198 & 90 & 20.08 & $\mathrm{Ca}$ & 13.04 & 100 & 10.05 & $\mathrm{Ne}$ \\
\hline 12.9248 & & 17.16 & $\mathrm{Cl}$ & 130411 & 800 & 13.04 & $\mathrm{Al}$ \\
\hline 12.928 & & 14.1 & $\mathrm{Si}$ & 13.0431 & 40 & 7.04 & $\mathrm{~N}$ \\
\hline 12.9322 & 10 & 20.1 & $\mathrm{Ca}$ & 13.0537 & 60 & 12.03 & $\mathrm{Mg}$ \\
\hline 12.9337 & 20 & 7.04 & $\mathrm{~N}$ & 13.061 & 18 & 10.04 & $\mathrm{Ne}$ \\
\hline 12.936 & 50 & 10.05 & $\mathrm{Ne}$ & 13.0624 & 80 & 12.03 & $\mathrm{Mg}$ \\
\hline 12.94 & 50 & 14.09 & $\mathrm{Si}$ & 13.063 & 100 & 12.05 & $\mathrm{Mg}$ \\
\hline 12.9423 & 250 & 20.08 & $\mathrm{Ca}$ & 13.068 & 16 & 10.04 & $\mathrm{Ne}$ \\
\hline 12.9448 & 90 & 20.08 & $\mathrm{Ca}$ & 13.068 & 200 & 11.04 & $\mathrm{Na}$ \\
\hline 12.9464 & 10 & 11.03 & $\mathrm{Na}$ & 13.07 & 20 & 12.03 & $\mathrm{Mg}$ \\
\hline 12.95 & 150 & 9.05 & $\mathrm{~F}$ & 13.0701 & 10 & 12.05 & $\mathrm{Mg}$ \\
\hline 12.9711 & 100 & 12.03 & $\mathrm{Mg}$ & 13.0723 & 100 & 11.04 & $\mathrm{Na}$ \\
\hline 12.9729 & & 12.11 & $\mathrm{Mg}$ & 13.074 & 30 & 10.04 & $\mathrm{Ne}$ \\
\hline 12.973 & 700 & 13.03 & $\mathrm{Al}$ & 13.077 & 16 & 10.04 & $\mathrm{Ne}$ \\
\hline 12.9785 & 450 & 8.05 & $\mathrm{O}$ & 13.0847 & 1000 & 13.04 & $\mathrm{Al}$ \\
\hline 12.9811 & 30 & 7.04 & $\mathrm{~N}$ & 13085 & 60 & 8.99 & $\mathrm{O}$ \\
\hline 12.9857 & 320 & 12.03 & $\mathrm{Mg}$ & 13.0883 & 1 & 20.1 & $\mathrm{Ca}$ \\
\hline 12.9871 & 550 & 8.05 & $\mathrm{O}$ & 13.1002 & 900 & 13.04 & $\mathrm{Al}$ \\
\hline 12.989 & 50 & 14.11 & $\mathrm{Si}$ & 13.1217 & 500 & 20.12 & $\mathrm{Ca}$ \\
\hline 12.9935 & 360 & 20.08 & $\mathrm{Ca}$ & 13.1254 & 50 & 7.04 & $\mathrm{~N}$ \\
\hline 12.9942 & 100 & 11.04 & $\mathrm{Na}$ & 13.1345 & 300 & 11.04 & $\mathrm{Na}$ \\
\hline 12.9966 & 220 & 12.03 & $\mathrm{Mg}$ & 13.136 & 54 & 10.05 & $\mathrm{Ne}$ \\
\hline 12.9973 & 90 & 20.08 & $\mathrm{Ca}$ & 13.1413 & 200 & 11.04 & $\mathrm{Na}$ \\
\hline 12.9975 & 180 & 12.03 & $\mathrm{Mg}$ & 13.1419 & 1 & 20.07 & $\mathrm{Ca}$ \\
\hline 13.002 & 20 & 14.11 & $\mathrm{Si}$ & 13.1438 & 900 & 13.04 & $\mathrm{Al}$ \\
\hline 13.0041 & & 12.11 & $\mathrm{Mg}$ & 13.146 & & 14.11 & $\mathrm{Si}$ \\
\hline 13.006 & & 13.11 & $\mathrm{Al}$ & 13.147 & 1 & 20.07 & $\mathrm{Ca}$ \\
\hline 13.0086 & 200 & 12.03 & $\mathrm{Mg}$ & 13.1516 & 10 & 9.04 & $\mathrm{~F}$ \\
\hline 13.0118 & 180 & 12.03 & $\mathrm{Mg}$ & 13.1633 & 650 & 19.08 & $\mathrm{~K}$ \\
\hline 13.0141 & & 12.11 & $\mathrm{Mg}$ & 13.1635 & 300 & 11.04 & $\mathrm{Na}$ \\
\hline 13.0191 & 90 & 20.08 & $\mathrm{Ca}$ & 13.1638 & 10 & 9.04 & $\mathrm{~F}$ \\
\hline 13.021 & & 13.11 & $\mathrm{Al}$ & 13.164 & 50 & 14.11 & $\mathrm{Si}$ \\
\hline 13.0246 & 140 & 12.03 & $\mathrm{Mg}$ & 13.1647 & 150 & 13.03 & $\mathrm{Al}$ \\
\hline 13.025 & 140 & 8.99 & $\mathrm{O}$ & 13.1738 & 20 & 8.04 & $\mathrm{O}$ \\
\hline 13.026 & 110 & 10.05 & $\mathrm{Ne}$ & 13.1758 & 40 & 8.04 & $\mathrm{O}$ \\
\hline 13.0294 & 200 & 12.05 & $\mathrm{Mg}$ & 13.1812 & 70 & 8.04 & $\mathrm{O}$ \\
\hline 13.0295 & 180 & 12.03 & $\mathrm{Mg}$ & 13.188 & 500 & 19.08 & $\mathrm{~K}$ \\
\hline 13.034 & 25 & 7.05 & $\mathrm{~N}$ & 13.199 & 45 & 10.04 & $\mathrm{Ne}$ \\
\hline
\end{tabular}


するために，トロイダルミラーを有する空間分解計測が できる斜入射分光器を用いてターゲット表面からの距離 と発生するEUVスペクトルの観察を行った. 分光器の観 察軸を固定した状態でターゲットと集光レンズの距離を 保つことによりターゲット上での照射強度を約 $5 \times 10^{11}$ $\mathrm{W} / \mathrm{cm}^{2}$ で保ち, レーザー光軸に沿って並行に移動させ, ターゲット表面から $4.5 \mathrm{~mm}$ でのEUVスペクトル観察を 行った結果の一例をFig. 3に示す.このスペクトルはそれ ぞれ一回のレーザー照射で得られたEUVスペクトルであ る。ターゲット表面ではBremsstrahlungあるいは放射再結 合による連続スペクトルと波長 $13 \mathrm{~nm}$ の線スペクトルが強 く観察され，イオン価の低いプラズマから発生する波長 $16 \mathrm{~nm}$ のUUV光は比較的弱く観察される.これに対し, ターゲット表面から離れるほど連続スペクトルやイオン 価の高いプラズマからのEUVスペクトルは弱くなり，イ オン価の低いプラズマからの線スペクトルが強くなって いる。これはレーザー照射されたターゲット表面は非常 に高温であり，プラズマが膨張して冷却する過程で低い イオン価のプラズマが形成されていると予測される.同 観察により得られたデータから, 波長 $13 \mathrm{~nm}$ のピーク強度 のターゲット法線方向に対する推移を Fig. 4に示す。この 結果に見られるように，ターゲット表面から $1 \mathrm{~mm}$ はなれ た位置で波長 $13 \mathrm{~nm}$ の強度が最大になっていることがわ かった。

そこでさらに詳細にプラズマの空間分布を調べるため に，ターゲット近傍に $250 \mu \mathrm{m}$ 幅のスリットを配置して，

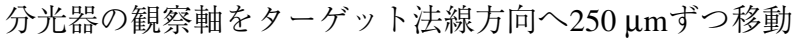
させ観察したスペクトルから波長 $13 \mathrm{~nm}$ と波長 $16 \mathrm{~nm}$ のピー ク強度を求め比率計算を行い，2次元的に示した結果を Fig. 5に示す. ターゲット面内方向の処理においては，観

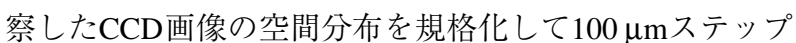
でデー夕処理を行った。また，ターゲット法線方向は データ処理時にステップ間のスムージングを行ってい

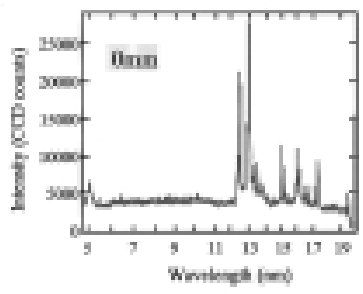

(a)

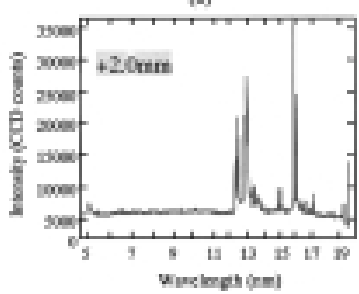

(c)
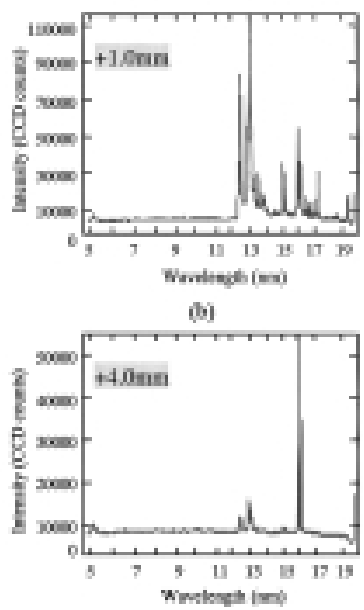

(d)
Fig. 3 Soft X-ray spectra from aluminum tape-target irradiated by a single YAG laser shot, observed through a silicon nitride filter, (a): at the target surface, (b): at $+1 \mathrm{~mm}$, (c): at $+2 \mathrm{~mm},(\mathrm{~d}):$ at $+4 \mathrm{~mm}$ from the target surface.

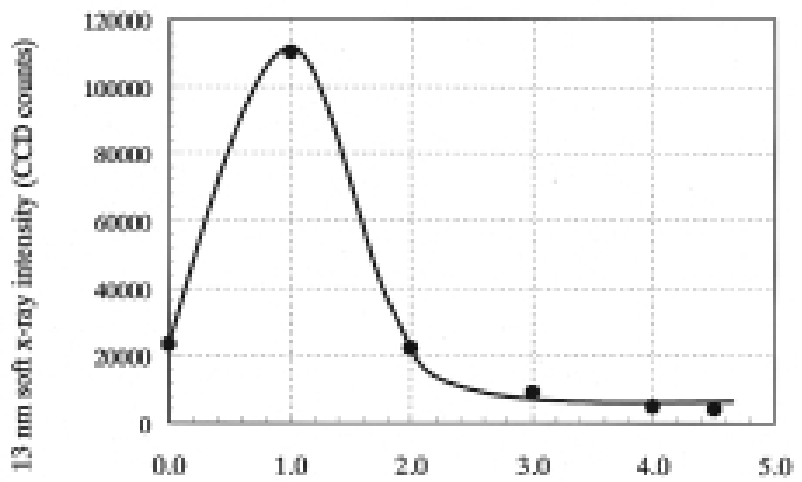

Distance from the target surface along target normal (mm)

Fig. 4 Spatial distribution of EUV light intensity at the wavelength of $13 \mathrm{~nm}$ along the target normal, when the position of observation was changed with every $500 \mu \mathrm{m}$ step.

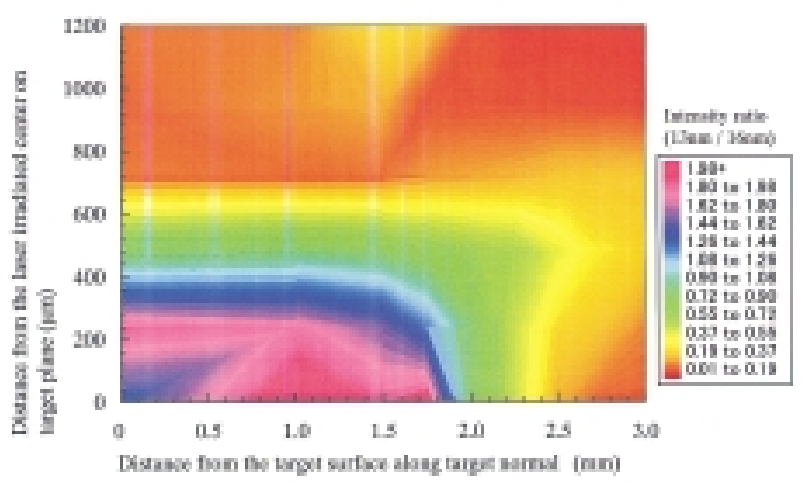

Fig. 5 Spatial distribution of the intensity ratio of the 13 $\mathrm{nm} / 16 \mathrm{~nm}$ soft X-ray from the aluminum tape-target irradiated with about $5 \times 10^{11} \mathrm{~W} / \mathrm{cm}^{2}$.

る. Fig. 5に示されるように，ターゲット表面付近ではイ オン価が高くなっていることがEUV光空間分布から明確 になった。

以上の結果より，生成されるレーザープラズマの空間 分布を利用して発光の単色化を眓ることが可能となる. アルミニウムテープターゲットの場合, EUV光の取出し 位置をターゲット表面より $1 \mathrm{~mm}$ 離れた場所に空間アパー チャを配置することにより，波長 $13 \mathrm{~nm}$ を効率良く取出す ことができることがわかった。

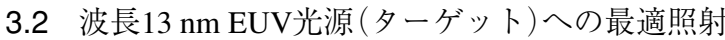 強度}

ターゲットへ照射する励起用レーザーの最適照射強度 に関する検討を行った，観察位置を前項で得られた結果 を基に，ターゲット法線方向に $1 \mathrm{~mm}$, 約 $600 \mu \mathrm{m}$ の測定視 野と固定し，ターゲットへの励起用レーザー照射強度を 約 $2 \times 10^{11} \sim 1.8 \times 10^{12} \mathrm{~W} / \mathrm{cm}^{2}$ と変化させたときに発生する EUVスペクトルを観察し, 波長 $13 \mathrm{~nm}$ ピーク強度変化を測 定した。測定に際して励起用レーザーの照射強度を変化 させるために，集光レンズホルダーに設けたステージを 用いて焦点をターゲット表面に対して移動させながら 行った。尚，ターゲット上の照射強度Iは，実際に照射し 
たターゲットの照射痕を顕微鏡で観察し，式(2)を用いて 算出した.

$$
I=\frac{E}{S \times t}\left[\mathrm{~W} / \mathrm{cm}^{2}\right]
$$

( $I=$ 照射強度, $S=$ 照射断面積, $t=$ 励起用レーザーパル ス幅)

Fig. 6に示すグラフは，照射強度に対する波長 $13 \mathrm{~nm}$ の ピーク強度推移を示したものである。この結果から， $4 \times$ $10^{11} \mathrm{~W} / \mathrm{cm}^{2}$ 程度のレーザー光を照射することで，波長 13 $\mathrm{nm}$ が最も強く発生していることがわかった．また， $5 \times$ $10^{11} \mathrm{~W} / \mathrm{cm}^{2}$ 以上の場合波長 $13 \mathrm{~nm}$ の強度が徐々に減衰して いたのでその理由を探るために観察したスペクトルを詳 細に調べた。 Fig. 7 に約 $4 \times 10^{11} \mathrm{~W} / \mathrm{cm}^{2}$ と約 $10 \times 10^{11} \mathrm{~W} / \mathrm{cm}^{2}$ の時の画像スペクトルを示す。この結果に見られるよう に照射強度が高くなったときは，波長 $4 \mathrm{~nm}$ 付近に $\mathrm{Al}^{8+}$, $\mathrm{Al}^{9+}$ イオンからの発光が確認されており, ターゲットに与 えたエネルギーが高価イオン生成に費やされたため，波 長13 nmの強度が低下したと思われる。

以上のことよりターゲット法線方向に $1 \mathrm{~mm}$ 離れた位置 をEUV光取出し位置とした場合，波長 $13 \mathrm{~nm}$ のEUV光を効 率良く発生させるためには $4 \times 10^{11} \mathrm{~W} / \mathrm{cm}^{2} \sim 5 \times 10^{11} \mathrm{~W} / \mathrm{cm}^{2}$ の範囲のターゲットへの照射強度が適していることがわ かった。

\section{3 光源位置での波長 $13 \mathrm{~nm}$ の放射強度の見積}

前項3.1及び3.2に示した実験を基に開発した装置に平面 結像型斜入射回折格子分光器を取り付け, 測定したスぺ クトルから光源位置における波長 $13 \mathrm{~nm}$ エネルギー放射 $(2 \pi \mathrm{sr} \cdot \pm 2 \% \mathrm{BW}$ あたり )を算出した，現在，EUV光の光源 位置での光量を測定する装置として，多層膜ミラーと半 導体センサーにより構成された装置(Flying Circus)が EUVL関連分野での評価標準として用いられているが，本 研究では現状ツールによる簡易計算にて大凡の放射量を 求める方法を採用することとした，光源位置での放射強

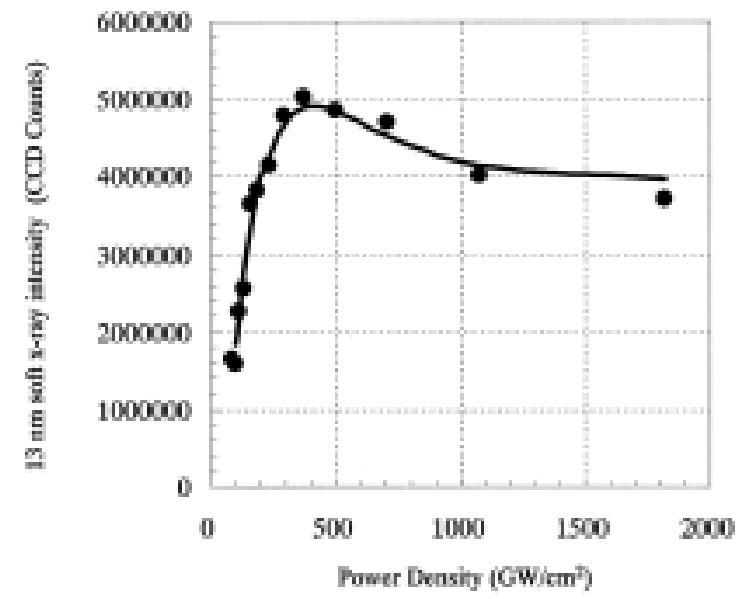

Fig. 6 Intensity of the $13 \mathrm{~nm}$ emission as a function of laser irradiation power density, where the irradiation intensity at aluminum tape-target surface is changed from about $2 \times 10^{11}$ to $1.8 \times 10^{12} \mathrm{~W} / \mathrm{cm}^{2}$.

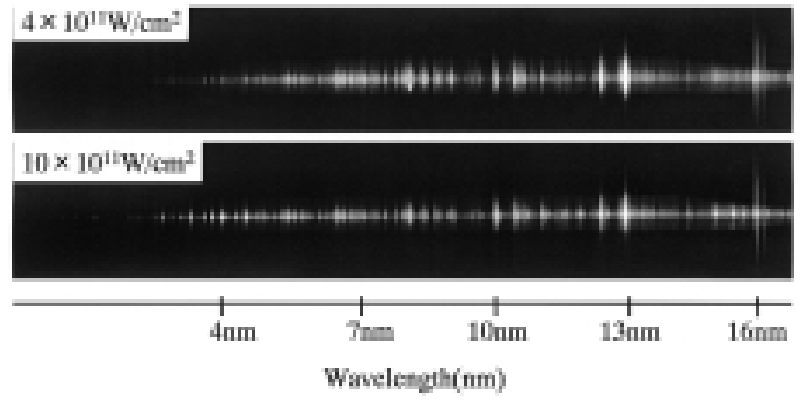

Fig. 7 Spectrophtographs obtained by using CCD camera. The power density is (a) $4 \times 10^{11} \mathrm{~W} / \mathrm{cm}^{2}$, or (b) $1.0 \times$ $10^{12} \mathrm{~W} / \mathrm{cm}^{2}$.

度測定実験の配置をFig. 8に示す. 同装置は光源から前置 ミラーまでの距離は $800 \mathrm{~mm}$, 同ミラーからスリット (100 $\mu \mathrm{m}$ 幅) までの距離が $95 \mathrm{~mm}$ ，同スリットから回折格子(日 立製：1200 lines/mm) までの距離が $237 \mathrm{~mm}$ ，同回折格子か らCCDカメラ (Princeton Instruments (Roper Scientific) 社製 :PI-SX:1300 back-illuminated セルサイズ:20 $\mu \mathrm{m} \times 20 \mu \mathrm{m}) ま$

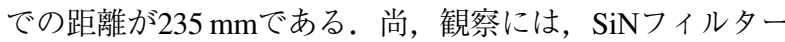
(厚さ $200 \mathrm{~nm}$ ) を分光器内に取り付け, Si L 殸吸収端 (波長 $12.4 \mathrm{~nm}$ )により高次回折光を除去するために用いた．分光 器内に入射した光子数を $N_{\text {in }}$ とするとCCDカメラからで検 出される発生する電子の個数Nは9)

$$
N=N_{\text {in }} \eta \varepsilon_{\mathrm{CCD}} \frac{h v}{3.65} \frac{1}{g}
$$

で表すことができる。ここで，hvは着目する光子のエネ ルギー $(\mathrm{eV}), \eta$ は回折格子の効率， $\varepsilon_{\mathrm{CCD}}$ はCCDの量子効率 $\varepsilon_{\mathrm{CCD}}=0.41, g$ は使用したCCDカメラのgain $(5 \mathrm{e}-/$ count $)$ であ る. 使用した回折格子の1次光回折効率は, 文献10)に示 されている結果から $\eta=0.04$ (理論計算值では 0.2 ) とし た。そして, CCDカタログ值から波長 $13 \mathrm{~nm}$ 付近の量子効 率 $\varepsilon_{\mathrm{CCD}}$ は約 $41 \%$ \%あった。 また，式(3)中の3.65はCCD素 子内の電子-正孔対生成エネルギー $(\mathrm{eV})$ である. 次に, 光 源位置での積分発光光子数を $N_{\mathrm{T}}$ とすると分光器に入射し た光子数 $N_{\text {in }}$ は，以下の式で表すことができる.

$$
N_{\text {in }}=N_{\mathrm{T}} \frac{\Omega}{2 \pi} T R S
$$

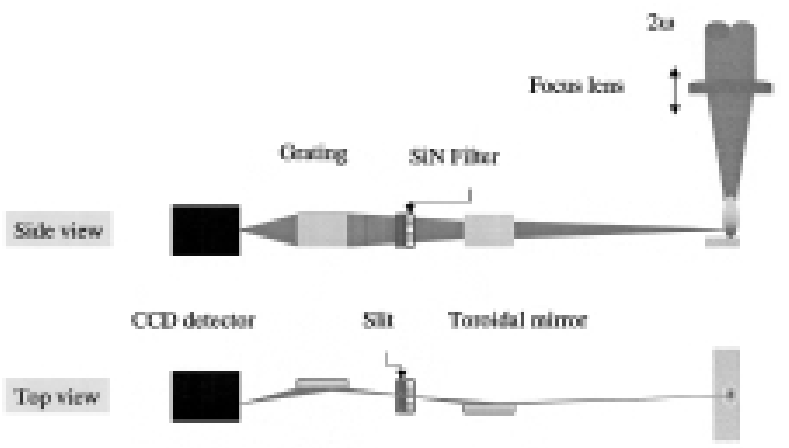

Fig. 8 Experimental layout for quantitative measurement of spectral emission intensity in the developed light source system. 
ここで, $\Omega$ は分光器前置鏡の受光立体角, Tはフィルター $(\mathrm{SiN})$ 透過率 $(\mathrm{T}=0.1), \mathrm{R}$ は前置鏡の理想反射率 $(\mathrm{R}=95$ $\%), \mathrm{S}$ は前置光学系に対する分光器スリット透過率であ る. 使用した分光器は, 分光器入口側で前置鏡面内方向 のEUV光源が一端集光される構造となっており, 実験配 置からスリット透過率は大凡 $S=1 / 4 \sim 1 / 5$ 程度となる.

シングル照射してプラズマを生成させ観察したスペク トル (Fig. 9)を数值データに変換し積分した值からCCDカ メラから発生する電子の個数 $\mathrm{N}$ 求め, 上述の計算式 （3），(4）を用いて光源位置での波長 $13 \mathrm{~nm}$ の放射強度を算 出した結果, 約 $4 \mathrm{~mJ} / 2 \pi \mathrm{sr} \cdot \pm 2 \% \mathrm{BW} \cdot \mathrm{pulse}$ であった. 本測 定に用いた前置鏡の反射率は表面の凹凸による散乱のた めに今回用いた值より小さい可能性があるので, 光源の 放射強度は上述の数值より大きくなっていると思われ る。

3.4 開発した光電子分析装置における光電子スペク トル観察結果と空間分解能

前節に示したような発光強度をもつEUV光源を $50 \mathrm{~Hz}$ 運転し, $A u$ 斜入射ミラーを介して2.3の光電子顕微鏡装置 に導いて光電子分析実験を行った. 用いた試料はGaAs化 合物半導体である. Fig. 10 (a) に示すように検出面に入る 光電子の運動エネルギーが47〜 $92 \mathrm{eV}$ 設定において, 2 つの光電子ピークが検出画像に明確に現われた。この時 のEUV光照射時間は10分であった. 本光電子分光器で分 析される電子のエネルギー絶対值の較正はまだ実施して いないが，相対值に関しては電子ビームを試料に照射し た時の弾性散乱ピークの測定を通して正確にわかってい る。画像に現われたピークは束縛エネルギーの関係か ら, 画面上に現われたものがAs 3d, 下側がGa 3d光電子に よるピークであると考えられる. 画像強度の運動エネル ギー軸に沿った分布をプロットしたものをFig. 10 (b)に示

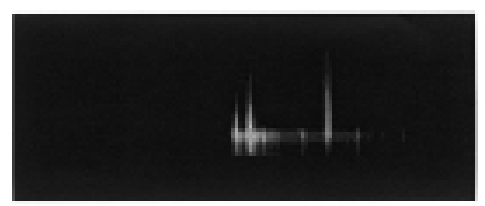

(a)

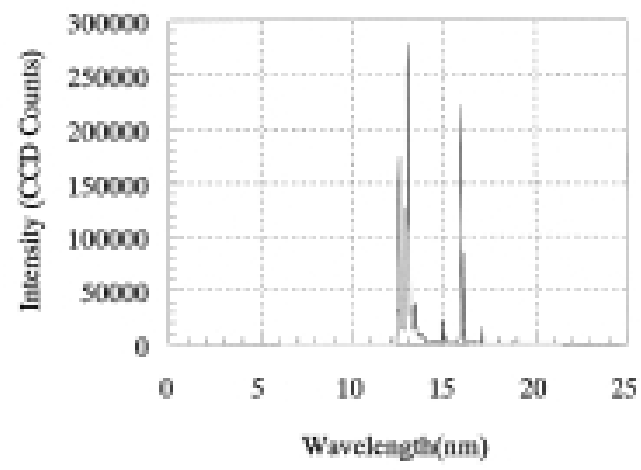

(b)

Fig. 9 (a) Observed CCD image. (b) Spectral distribution deduced from the image. The spectrum was obtained in a single laser shot.
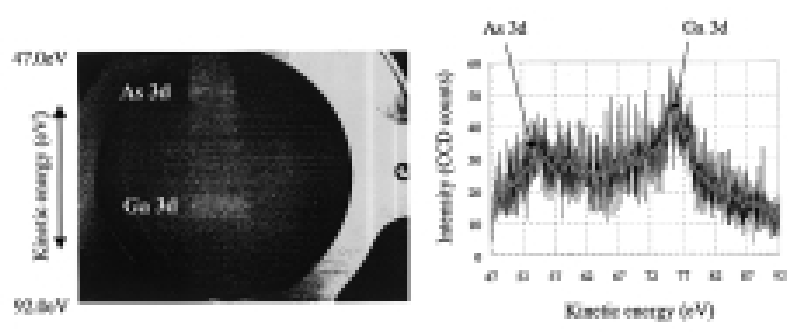

Fig. 10 (a) Photoelectron output image of the XPS system. (b) Profile of photoelectron intensity as a function of its kinetic energy. Sample is GaAs wafer. Exposure of EUV light is $10 \mathrm{~min}$.

す。これは通常のXPS装置で得られる光電子スペクトル曲 線に相当する．2つのスペクトルピークが明瞭に認めら れ，その間隔は約 $21 \mathrm{eV}$ である。単体の $\mathrm{Ga}$ およびAsの3d電

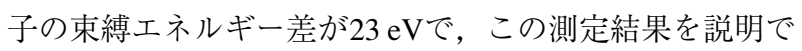
きないのに対し, GaAs中の Ga 3d, As 3d束縛エネルギー 差は $21.3 \mathrm{eV}$ であり, 観測結果とよく一致する。従って, 今回の測定によって GaAs化合物からの Gaと Asの光電子を 観測できた. Fig. 10 (b)のエネルギー軸の目盛の絶対值は As $3 \mathrm{~d}$ 光電子の運動エネルギー $(53.9 \mathrm{eV})$ に合わせて表示し てある．以上のように，開発したレーザープラズマEUV 光源を用いた光電子分析システムにより, 試料の光電子 分析が行えることが示された。

次に開発した光電子顕微鏡装置の空間分解能を調べる ために, GaAs試料表面にレジストを幅 $20 \mu \mathrm{m}$ 毎に塗布した

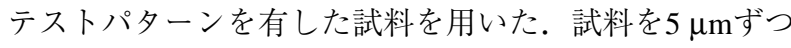
移動しながら光電子スペクトル観察を行い, As 3d光電子 信号強度の変化を調べた。尚，同測定は豊田工業大学に おいて本研究で用いたアルミニウムテープターゲットに よるレーザープラズマEUV光源装置を用いて実施され た.その結果をFig. 11に示す。同図は横軸に試料移動量, 縦軸にその時のAs $3 \mathrm{~d}$ 光電子スペクトル強度を示してあ る. 測定結果から大凡の空間分解能を推定すると約 $5 \mu \mathrm{m}$ 以下であることがわかった。このようにして決めた空間 分解能は試料上の大凡のEUV光集光サイズを反映してい ると考えられ, シュバルッシルトミラーの設計值 (倍率 $1 / 244, \mathrm{NA}=0.25$, 設計中心波長 $13.1 \mathrm{~nm} \pm 0.1 \mathrm{~nm}$ ) から, 光源の大きさは約 $700 \mu \mathrm{m}$ 程度であることが予測される. 通常「生成されるプラズマサイズ」=「光源サイズ」となる ため，生成されるプラズマを小さくすることが空間分解 能を向上させる方法として考えられる．生成されるプラ ズマサイズを小さくする方法として例えば，励起用レー ザー光のパルス幅を短くしたりすることで少しは小さく することも可能である. しかしながら本手法の特徵は, 生成されるプラズマの空間分布を活用し, 必要となる波 長を効率良く取り出すことにある。そこで，デブリの飛 散量が少ない位置であるターゲット法線から 80 度から 90 度傾いた位置 ${ }^{11)}$ に200 $\mu \mathrm{m}$ 以下のピンホールを配置するこ とにより，デブリによるピンホールのダメージも少な く，生成されるプラズマの空間分布を利用したサブミク ロンの空間分解能をもった光電子顕微鏡装置を実現する ことが可能であると予測される。 


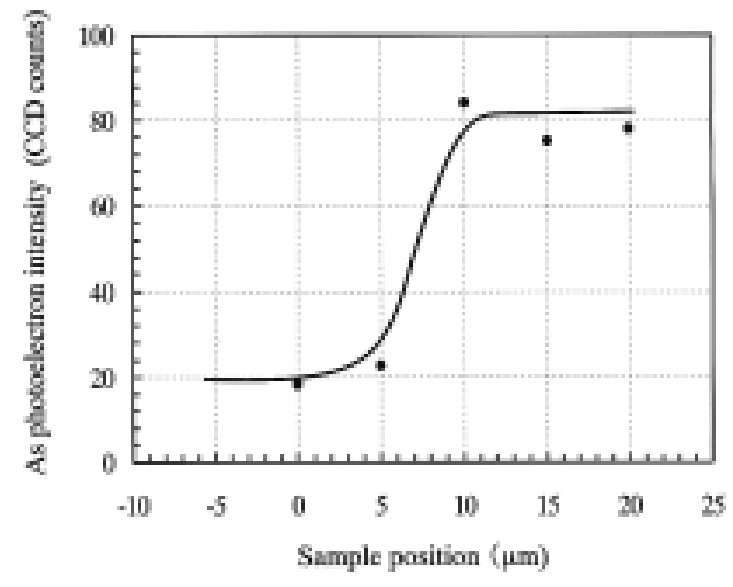

Fig. 11 Intensity of the As $3 \mathrm{~d}$ peak as a function of the irradiated position in the GaAs sample. The surface of the sample was coated with a line and space pattern of photoresist whose width was $20 \mathrm{~mm}$.

\section{4. まとめ}

レーザープラズマEUV光源による光電子分析装置を試 作し, 同装置の光源の特性, 光電子スペクトル観察を 行った. その結果, 光電子分析装置に必要なレーザープ ラズマEUV光を得るには, 励起用レーザー光の最適照射 強度があり，アルミニウムテープターゲットを用いた場 合, ターゲット上で約 $400 \mathrm{GW} / \mathrm{cm}^{2} \sim 500 \mathrm{GW} / \mathrm{cm}^{2}$ のエネル ギーが必要であることがわかった。また，生成されるプ ラズマには空間分布が存在し, 同ターゲットにおいては ターゲット表面から約 $1 \mathrm{~mm}$ 離れた位置を観察(取出し)位 置とすることがよいことがわかった，また，生成される レーザープラズマEUV光の光源位置での放射強度は約 4 $\mathrm{mJ} / 2 \pi \mathrm{sr} \cdot \pm 2 \% \mathrm{BW} \cdot$ pulseであった.

開発したレーザープラズマEUV光源を用いることによ り光電子スペクトル観察が可能となり, GaAsからのGa 3d とAs 3dの光電子スペクトルの観察が可能な価電子帯励起 の光電子分析装置を開発することが出来た. そして試料 上での空間分解能は現状で約 $5 \mu \mathrm{m}$ 以下を得ることができ ている.

今後は, 開発した装置の空間分解能向上並びに同光源
の更なる最適化を実施すること，試料を2次元的にスキャ ニングすることにより光電子の顕微分析が行えるように することを目標としていく，後者に関して，測定データ を画像化する技術についても検討を進めていきたい. 更 には，よりエネルギーの高い光源を開発し内殼 (Si 2pな ど)の光電子スペクトル観察が可能な装置開発を進めてい く予定である.

\section{謝 辞}

本研究の一部は, 文部科学省, 科学技術振興調整費に よる「顕微光電子分光法による材料・デバイスの高度分析 評価技術に関する研究」並びに経済産業省「地域新生コン ソーシアム事業」により行われました。ここに記して謝意 を表します。

アルバックファイ(株)渡邊勝巳様には, エネルギー分 散型分析装置の改造, 調整を行っていただき有益な議論 をさせていただきました。ここに記して謝意を表しま す.

\section{参考文献}

1) W. Ng, A. K. Ray-Chaudhuri, S. Liang, S. Singh, H. Solak, J. Welnak, F. Cerrina, G. Margaritondo, J. B. Underwood, J. H. Koetright, and R. C. C. Perera: Nucl. Instrum. Meth. Phys. Res. A 347 (1994) 422

2) F. Barbo, M. Bertolo, A. Bianco, G. Cautero, S. Fontana, T. K. Johai, S. La Rosa, G. Margaritondo, and K. Kazanacheyev: Rev. Sci. Instrum. 71 (2000) 5.

3) H. Kondo, T. Tomie, and H. Shimizu: Appl. Phys. Lett. 72 (1998) 2668.

4) 西村 靖彦, 坂田 篤, 東博 純: 秋季 第61回応用物理学会学術 講演会予稿集 $(2000) 578$; 応用物理学会.

5) 西村靖彦他：第23回年次大会レーザー学会 (2002).

6) Raymond L. Kelly: Atomic and ionic Spectrum lines below 2000 Angstroms: Hydrogen through krypton; J. Chem. Ref. Data, Vol. 16, supple. 1, (1987)

7) 大道博行：レーザー研究 27 (1999) 3.

8）西村靖彦他：レーザー研究 29 (2001) 659.

9) C. Fujikawa, N. Yamaguchi, T. Hara, T. Kawachi, H. Oyama, K. Ando, and Y. Aoyagi: Rev. Sci. Instrum. 69 (1998) 2849.

10) W. Schwanda, K. Eidmann, and M. C. Richardson: J. X-ray Sci. and Technol. 4 (1993) 8.

11) H. Azuma, Y. Nishimura, A. Sakata, and A. Takeuchi: Appl. Surf. Sci. 197-198 (2002) 224 